\title{
DEGRADATION OF H-ACID BY FREE AND IMMOBILIZED CELLS OF ALCALIGENES LATUS
}

\author{
Usha M.S.*, Sanjay M.K., Gaddad S.M., Shivannavar C.T.
}

Department of P. G. Studies and Research in Microbiology, Gulbarga University, Gulbarga-585106, Karnataka, India.

Submitted: January 07, 2010; Returned to authors for corrections: February 11, 2010; Approved: April 26, 2010.

\begin{abstract}
Alcaligenes latus, isolated from industrial effluent, was able to grow in mineral salts medium with $50 \mathrm{ppm}$ $(0.15 \mathrm{mM})$ of $\mathrm{H}$-acid as a sole source of carbon. Immobilization of Alcaligenes latus in Ca-alginate and polyurethane foam resulted in cells embedded in the matrices. When free cells and immobilized cells were used for biodegradation studies at concentration ranging from $100 \mathrm{ppm}(0.3 \mathrm{mM})$ to $500 \mathrm{ppm}(1.15 \mathrm{mM})$ degradation rate was enhanced with immobilized cells. Cells immobilized in polyurethane foam showed $100 \%$ degradation up to $350 \mathrm{ppm}(1.05 \mathrm{mM})$ and $57 \%$ degradation at $500 \mathrm{ppm}(1.5 \mathrm{mM})$. Degradation rate of Ca-alginate immobilized cells was less as compared to that of polyurethane foam immobilized cells. With Ca-alginate immobilized cells $100 \%$ degradation was recorded up to $200 \mathrm{ppm}(0.6 \mathrm{mM})$ of $\mathrm{H}$-acid and only $33 \%$ degradation was recorded at $500 \mathrm{ppm}(1.5 \mathrm{mM})$ of $\mathrm{H}$-acid. Spectral analysis of the products after $\mathrm{H}$-acid utilization showed that the spent medium did not contain any aromatic compounds indicating H-acid degradation by A. latus.
\end{abstract}

Key words: H-acid, biodegradation, immobilized cells, Alcaligenes latus

\section{INTRODUCTION}

Synthetic dyes have been extensively used in textile, power loom and dying industries. Azo dyes constitute more than $50 \%$ of the dyes produced globally (22). Almost $10-$ $15 \%$ of the dyes produced are discharged in the effluents (49). The amino and hydroxy naphthalene sulphonic acids are building blocks of azo dyes and the sulphonic acid group confers a xenobiotic character to this class of chemicals (41). The amino groups as additional substituents add polarity to these xenobiotics, which may further resist biodegradation. Even these xenobiotic compounds are partially degraded by certain bacteria and algae; they utilize naphthalene sulphonic acids as a source of sulfur.

Certain bacteria and algae have been reported to utilize naphthalene sulphonic acids as a source of sulfur $(21,43,48$,
50). Kneifel et al. (21) showed that under sulfate limitation, axenic batch cultures of the green alga Scenedesmus obliquus could metabolize 1-naphthalene sulfonic acid and partially use the sulfonate as a source of sulfur. A small amount of 1naphthalene sulfonic acid was desulfonated. The resulting 1naphthol was mostly transformed into 1-naphthyl $\beta$-Dglucopyranoside. According to Soeder et al. (43) 1-naphthalene sulfonate was utilized by axenic cultures of Scenedesmus obliquus and by five other green microalgae as the sole source of sulfur. 1-naphthol appeared as the major metabolite of 1naphthalene sulfonate. Hence, they concluded that 1naphthalene sulfonate underwent a desulfonation. Zurrer et al. (50) showed that a Pseudomonas sp., an Arthrobacter sp. and an unidentified bacterium isolated from sewage could desulfonate at least 16 aromatic compounds none of which served as carbon source. Pseudomonas sp. strain S-313 
converted 1-naphthalene sulfonic acid, 2-naphthalene sulfonic acid, 5-amino 1-naphthalene sulfonic acid, benzene sulfonic acid and 3-aminobenzene sulfonic acid to 1-naphthol, 2naphthol, 5-amino 1-naphthol, phenol and 3-aminophenol respectively.

Feigel and Knackmuss (15) have reported degradation of 4-aminobenzene sulphonic acid in a co-metabolism by two species of bacteria. Hydrogenophaga deaminated 4aminobenzene sulphonic acid by regioselective 3,4dioxygenation. The major part of the metabolite was catechol 4-sulfonate which was further metabolized by Agrobacterium radiobacter. Nortemann et al. (33) showed that Pseudomonas sp. BN6 could oxidize 1- and 2-naphthalene sulfonate, 1hydroxynaphthalene 2-sulfonate, 2,6-naphthalene disullfonate and all monosulfonated naphthalene 2-sulfonates which carry one or two substitutents in the positions 4-, 5-, 6-, 7- or 8- of the naphthalene ring system with the exception of 4- or 5amino and 4-hydroxynaphthalene 2-sulfonates. These compounds were converted to the corresponding salicylates. However the strain BN6 did not oxidize substituted naphthalene 1-sulfonates, naphthalene 3-sulfonates and naphthalene disulfonates. 5-Hydroxyquinoline 2-carboxylic acid was obtained as an end product from the degradation of 5Amino naphthalene 2-sulfonic acid by Pseudomonas sp. (32). The formation of 5-hydroxyquinoline 2-carboxylate prevented $\mathrm{NADH}$ regeneration and further oxidation of 5-amino naphthalene 2-sulfonic acid was limited by the internal NADH pool. Moraxella sp. isolated from industrial sewage plant could degrade Naphthalene 2, 6 and Naphthalene 1, 6 disulfonic acids (48). Regioselective 1,2-dioxygenation caused desulfonation of the compound resulting in accumulation of 5sulfosalicylic acid which also could be used as the sole carbon source. 5-Sulfosalicylic acid grown cells exhibited high gentisate 1,2-dioxygenase activity. Bacteria degrading amino hydroxy naphthalene sulphonic acids have been isolated from river Elbe by Nortemann et al. (31). The complete degradation of 6-aminonaphthalene 2-sulfonic acid was carried out by a mutualistic interaction of two Pseudomonas strains. Strain BN6 effected the initial conversion of the compound into 5- aminosalicylate through regioselective attack of the naphthalene skeleton in 1,2- position . 5-aminosalicylate was totally degraded by strain BN9. After prolonged adaptation of strain BN6 to growth on 6-aminonaphthalene 2-sulfonic acid, this organism readily converted all naphthalene 2-sulfonates with $\mathrm{OH}-$ or $\mathrm{NH}_{2}$ - substituents in 5-, 6-, 7- or 8- position. The corresponding hydroxy or aminosalicylates were excreted in stoichiometric amounts.

H-acid (1-amino 8-hydroxy naphthalene 3, 6-disulfonic acid) is a xenobiotic compound (PAH) used as a precursor in the preparation of several azo dyes and is resistant to degradation by all most all microorganisms. Degradation of $\mathrm{H}$ acid by physico chemical methods has been worked out by few investigators $(30,38,45)$. However, there are limited reports on biodegradation of $\mathrm{H}$-acid $(40,27)$.

Immobilized cells have been defined as cells that are entrapped within or associated with an insoluble matrix. Mattiasson (26) discussed various methods of immobilization: covalent coupling, adsorption, entrapment in a threedimensional polymer network, confinement in a liquid-liquid emulsion and entrapment within a semi permeable membrane. Entrapment in three-dimensional polymer network is widely used for immobilization studies. Various matrices, such as Kcarrageenan, alginate, agar, polyacrylamide-hydrazide and polyurethane foam, have been successfully used for immobilization of microorganisms $(7,8,16,26)$.

Under many conditions, immobilized cells have advantages over either free cells or immobilized enzymes. Immobilization imparts more operational flexibility due to the fact that it prevents biomass washout in continuous flow reactors, allows the use of higher cell densities than those obtainable with free cell systems, facilitates the separation of biomass from the treated effluent and offers the potential for improving wastewater treatment and solves the problems associated with solid-liquid separation in settling tanks $(5,11)$. Use of immobilized cells permits the operation of bioreactors at flow rates that are independent of the growth rate of the microorganisms employed (34). Catalytic stability can be greater for immobilized cells than for free cells and some 
immobilized microorganisms tolerate higher concentrations of toxic compounds than do their non-immobilized counter parts $(20,47)$.

Bioremediation using immobilized bacterial cells for the degradation of benzene was first shown by Somerville et al. (44) using polyacrylamide as immobilizing matrix. Bioremediation with immobilized cells in various matrices has been widely investigated for numerous toxic chemicals such as phenol $(2,19,29)$, pentachlorophenol $(6,35)$, 4-chlorophenol $(1,47)$, pyridine $(23)$ and naphthalene $(24,25)$.

Manohar et al. (25) reported the higher rate of naphthalene degradation by Pseudomonas sp. strain NGK1 immobilized in polyurethane foam than other matrices (alginate, agar and polyacrylamide) tested and free cells. Polyurethane foam was used as an excellent support for the immobilization of microbial cells for their use in the production of fuels chemicals (16). Joshi and D'souza (18) reported the immobilization of activated sludge for the degradation of phenol. Mordocco et al. (28) studied the effect of parameters such as $\mathrm{pH}$, temperature and dilution rate and bead diameter on the alginate-immobilized cells of Pseudomonas putida for the continuous degradation of phenol at low concentration. There was an enhanced mineralization of pentachlorophenol when Pseudomonas sp. UG30 cells were immobilized in $\mathrm{K}$ carrageenan compared to free cells (6).

Pseudomonas paucimobilis cells immobilized in $\mathrm{Ca}-$ alginate-phytagel was able to degrade sulfanilic acid (4-amino benzene sulphonic acid). The compound was used as sole carbon and nitrogen source. Immobilization in $\mathrm{Ca}$-alginatephytagel did not alter biodegradation activity of the organism (36). Production rate of $\mathrm{CO}_{2}$ was checked during degradation of 6-amino-2-naphthalene sulphonic acid by bacteria immobilized on sand particles. A linear correlation between $\mathrm{CO}_{2}$ formation and growth rate was found for submerged growing cultures as well as for bacteria immobilized on sand particles (13). The present work reports the enhancement of the degradation of $\mathrm{H}$-acid by Alcaligenes latus.

\section{MATERIALS AND METHODS}

\section{Chemicals}

$\mathrm{H}$-acid and other chemicals used in the present investigation were obtained from Hi-media (Bombay) (Figure 1).<smiles>Nc1cc(S(=O)(=O)O)cc2cc(S(=O)(=O)O)cc(O)c12</smiles>

Figure 1. H-acid (1-Amino 8-Hydroxy Naphthalene 3,6disulfonic acid)

\section{Media for $\mathbf{H}$-acid degradation studies}

Mineral salts medium of Brilon et al. (3) (12 g $\begin{array}{lllllllll}\mathrm{Na}_{2} \mathrm{HPO}_{4} .2 \mathrm{H}_{2} \mathrm{O}, & 2 & \mathrm{~g} & \mathrm{KH}_{2} \mathrm{PO}_{4}, & 0.5 & \mathrm{~g} & \mathrm{NH}_{4} \mathrm{NO}_{3}, & 0.1 & \mathrm{~g}\end{array}$ $\mathrm{MgCl}_{2} \cdot 6 \mathrm{H}_{2} \mathrm{O}, 50 \mathrm{mg} \mathrm{Ca}\left(\mathrm{NO}_{3}\right)_{2} \cdot 4 \mathrm{H}_{2} \mathrm{O}, 7.5 \mathrm{mg} \mathrm{FeCl}_{2} \cdot 4 \mathrm{H}_{2} \mathrm{O}$ and $0.1 \mathrm{ml}$ trace elements solution per liter of medium (37)) containing $50 \mathrm{ppm}(0.15 \mathrm{mM}) \mathrm{H}$-acid, $100 \mathrm{mg} / \mathrm{l}$ of yeast extract and $100 \mathrm{mg} / \mathrm{l}$ of dextrose was used for the degradation of $\mathrm{H}$ acid by $A$. latus.

For alginate-entrapped cells, the degradation medium contained $(\mathrm{g} / \mathrm{l}) \mathrm{K}_{2} \mathrm{HPO}_{4} 0.15, \mathrm{MgSO}_{4} .7 \mathrm{H}_{2} \mathrm{O} \quad 0.2, \mathrm{NH}_{4} \mathrm{Cl} 1.0$, $\mathrm{FeCl}_{3} 0.05$ and $\mathrm{CaCl}_{2}$ 0.2. The $\mathrm{pH}$ of the medium was adjusted to 7 (24). Different concentrations of H-acid (100 ppm (0.3 $\mathrm{mM})$ to $500 \mathrm{ppm}(1.5 \mathrm{mM}))$ were added as the sole carbon source.

\section{Immobilization of Bacterial cells}

Immobilization in Ca-alginate: The alginate entrapment of cells was performed according to the method of Bettman and Rehm (2). Alginate (4\% w/v) was dissolved in boiling water and autoclaved at $121^{\circ} \mathrm{C}$ for $15 \mathrm{~min}$. Bacterial suspension $(5 \%$ w/v) was added to $100 \mathrm{ml}$ sterilized alginate solution and 
mixed by stirring on a magnetic stirrer. This alginate/cell mixture, with stirring, was extruded drop by drop into a cold, sterile $0.2 \mathrm{M} \mathrm{CaCl}_{2}$ solution through a burette connected to a tapered pipette tip, by blowing air from the other end of the burette. Gel beads of approximately $2 \mathrm{~mm}$ diameter were obtained. The beads were hardened by resuspending into a fresh $\mathrm{CaCl}_{2}$ solution for $2 \mathrm{~h}$ with gentle agitation. Finally these beads were washed with distilled water and used for experimentation.

\section{Immobilization in Polyurethane foam}

A cell suspension was prepared by mixing $10 \mathrm{~g}$ of the cell paste (centrifuged pellet with little bit of moisture) with $20 \mathrm{ml}$ of buffer (carbon-free growth medium). One part of polyurethane pre-polymer was cooled on ice. One part (weight/weight) of buffer was added and the mixture was stirred well for one min. One part of the cell suspension was added, and mixing was continued for an additional one min. An additional part of the cell suspension was then added and mixing was continued for another one min. Cell-free foam was made for use as a control by substituting buffer for the cell suspensions. The reaction vessel was kept on ice for $2 \mathrm{~h}$ while the polyurethane foam hardened. The foam was removed from the reaction vessel, rinsed with buffer to remove free cells and stored at $4{ }^{\circ} \mathrm{C}$. At the beginning of each experiment the foam was rinsed three times with buffer to remove any free cells released during cutting of the foam (35).

\section{Biodegradation studies}

\section{Batch degradation studies:}

\section{With free cells system}

To carry out biodegradation studies with free cells $10 \mathrm{ml}$ $\left(8 \times 10^{10} \mathrm{CFU} / \mathrm{ml}\right)$ of Alcaligenes latus culture was added to each flask with $100 \mathrm{ml}$ of mineral salts medium, $10 \mathrm{mg}$ of yeast extract and different concentrations of H-acid (100 ppm (0.3 $\mathrm{mM})$ to $500 \mathrm{ppm}(1.5 \mathrm{mM}))$. The flasks were incubated at

$37^{\circ} \mathrm{C}$ and at $180 \mathrm{rpm}$ for $24 \mathrm{~h}$.

\section{With immobilized systems}

For biodegradation experiment with Ca-alginate, $5 \mathrm{~g}$ (wet weight) of beads, containing the immobilized Alcaligenes latus cells, were placed in $250 \mathrm{ml}$ flasks containing $100 \mathrm{ml}$ mineral salts medium and $\mathrm{H}$-acid was added at concentrations ranging from $100 \mathrm{ppm}(0.3 \mathrm{mM})$ to $500 \mathrm{ppm} 1.5 \mathrm{mM})$. The flasks were placed in a rotary shaker at $180 \mathrm{rpm}$ at $37^{\circ} \mathrm{C}$ for $24 \mathrm{~h}$.

Similarly $2 \mathrm{~g}$ of polyurethane foam with immobilized Alcaligenes latus cells were added to $100 \mathrm{ml}$ of mineral salts medium containing $\mathrm{H}$-acid at varying concentrations from 100 ppm $(0.3 \mathrm{mM})$ to $500 \mathrm{ppm}(1.5 \mathrm{mM})$. Flasks were placed in a rotary shaker at $180 \mathrm{rpm}$ at $37^{\circ} \mathrm{C}$ for $24 \mathrm{~h}$.

To determine whether the $\mathrm{H}$-acid was absorbed by the immobilization matrices or not control flasks were kept for incubation with cell free $\mathrm{Ca}$-alginate beads and polyurethane foams separately with different concentrations of $\mathrm{H}$-acid in 100 $\mathrm{ml}$ of mineral medium.

\section{Repeated Batch degradation studies}

To observe the long-term stability of $\mathrm{H}$-acid degradation by immobilized cells in different matrices, the system was used for repeated batch degradation. After each cycle of incubation period ( $24 \mathrm{~h}$ ), the spent medium was decanted and beads/ foam were washed with sterile water and transferred into a fresh sterile mineral salts medium $(100 \mathrm{ml})$ containing $200 \mathrm{ppm}(0.6 \mathrm{mM})$ of $\mathrm{H}$-acid. The degradation process was carried out as described above and the spent medium was used for the analysis of $\mathrm{H}$-acid degraded.

\section{Continuous degradation studies}

The continuous treatment of $\mathrm{H}$-acid was carried out in a continuous flow reactor. The reactor was filled with immobilized $A$. latus cells in different matrices. The degradation process was carried out by continuous supply of sterile mineral salts medium/minimal mineral salts medium containing $\mathrm{H}$-acid at different concentrations with constant flow rate $(\mathrm{ml} / \mathrm{h})$ with the help of peristaltic pump (Miclins PP10-4C, India).

Design of bioreactor for continuous treatment: A cylindrical glass column $(4 \times 50 \mathrm{~cm}$, volume $650 \mathrm{ml})$ with inlet and outlet facilities was used. The bottom of the column was 
packed with a glass wool ( $4 \mathrm{~cm}$ diameter) followed by a porous glass-frit. Then the reactor was packed with the respective immobilized cell matrix to a height of $30 \mathrm{~cm}$. The reactor was attached to a reservoir containing mineral salts medium/minimal mineral salts medium with $\mathrm{H}$-acid. The medium was fed into the column continuously with the help of a peristaltic pump (Miclins PP10-4C, India) through a side arm present near the bottom of the column. The medium after $\mathrm{H}$ acid degradation was continuously removed from the side arm situated just above the packed bed. The detention time was calculated by the following formula.

Detention time: void volume / flow rate $(\mathrm{ml} / \mathrm{h})$.

Degradation Rate $(\mathrm{R})=(\mathrm{Ci}-\mathrm{Ce}) \times \mathrm{D}$

Where $\mathrm{Ci}=$ Concentration of $\mathrm{H}$-acid in the influent

$\mathrm{Ce}=$ Concentration of $\mathrm{H}$-acid in the effluent

$\mathrm{D}=$ Dilution rate $=$ Flow rate $(\mathrm{ml} / \mathrm{h}) /$ Void volume of the reactor $(\mathrm{ml})$

\section{Estimation of per cent degradation of $\mathrm{H}$-acid}

At regular intervals a portion of the cultures were withdrawn and collected from the effluent in case of continuous system, centrifuged to remove cells and debris. The absorbance of clear supernatants was read at $390 \mathrm{~nm}$. The concentrations of the $\mathrm{H}$-acid were calculated by referring to the calibrated curve and the percent of the $\mathrm{H}$-acid degraded were then estimated.

\section{Cell viability enumeration}

To enumerate viable cells in the Ca-alginate beads, beads were washed in saline and one bead was soaked in $1 \mathrm{ml}$ of saline. Soaked bead was shaken with glass beads for $15 \mathrm{~min}$. Sample was plated onto nutrient agar and viable cells were expressed as CFU/ml after overnight incubation $(15 \mathrm{~h})$ at $37^{\circ} \mathrm{C}$.

For enumeration of viable cells in the PUF (polyurethane foam), PUF were rinsed with saline. One PUF was then torn into fine pieces using sterile forceps, suspended in saline and vortexed to dislodge the immobilized cells. Sample was then plated onto nutrient agar and viable cells were counted after overnight incubation $(15 \mathrm{~h})$ at $37^{\circ} \mathrm{C}$.

\section{Confirmation of $\mathbf{H}$-acid degradation}

In order to confirm degradation of $\mathrm{H}$-acid by A. latus, the products were extracted from the large amount of spent medium (after centrifugation at $8000 \times \mathrm{g}$ for $10 \mathrm{~min}$ ) using two volumes of diethyl ether. Thus extracted products were separated and characterized using TLC, ${ }^{1} \mathrm{H}$ NMR and IR analysis.

The separated diethyl ether fractions were dried over anhydrous sodium sulphate and the traces of sulphate from the filtrate were removed by anhydrous barium chloride. The metabolites were isolated and purified by TLC.

Thin layer chromatography was carried out by using a glass plate $(20 \times 10 \mathrm{~cm})$ coated with silica gel G slurry $(1: 2$ $\mathrm{w} / \mathrm{v}$ in water), dried and kept in oven at $100^{\circ} \mathrm{C}$ for $2 \mathrm{~h}$. Solvent systems used were chloroform: acetone (80:20) and cyclohexane: ethylacetate: acetone (4:1:1). Spots were observed after exposing the plates to iodine vapors. $\mathrm{H}$-acid and other aromatic compounds were used as a control to compare with degraded products of $\mathrm{H}$-acid.

The bands obtained on the chromatogram were separated and compounds were eluted with diethyl ether. The compounds were then kept for evaporation and sent to I.I.Sc., Bangalore and CDRI, Lucknow for IR and NMR analysis.

\section{RESULTS}

The results of $\mathrm{H}$-acid degradation in batch system by free cells are presented in Figures 2 and 3. It can be observed that $100 \%$ degradation upto $100 \mathrm{ppm}(0.3 \mathrm{mM})$ of $\mathrm{H}$-acid within 18 h. Further increase in $\mathrm{H}$-acid concentration resulted in decrease in the efficiency of $\mathrm{H}$-acid degradation to $65 \%$ at $150 \mathrm{ppm}$ (0.45 mM), 50\% at $200 \mathrm{ppm}(0.6 \mathrm{mM})$, and $35 \%$ at $300 \mathrm{ppm}$ $(0.9 \mathrm{mM})$ and less than $25 \%$ at $350 \mathrm{ppm}(1.05 \mathrm{mM})$ and above. At $500 \mathrm{ppm}(1.5 \mathrm{mM})$, the percent degradation was observed to be $15 \%$ only even after $48 \mathrm{~h}$ of incubation.

The results of degradation of $\mathrm{H}$-acid in batch systems by A. latus immobilized in Ca-alginate and polyurethane foam are shown in Figures 2 and 3. A. latus immobilized in polyurethane 
foam showed $100 \% \mathrm{H}$-acid degradation upto a concentration of $350 \mathrm{ppm}(1.05 \mathrm{mM})$ compared to $200 \mathrm{ppm}(0.6 \mathrm{mM})$ with cells embedded in Ca-alginate and only $100 \mathrm{ppm}(0.3 \mathrm{mM})$ with free cells. Degradation efficiency of polyurethane immobilized cells was observed to decrease at higher concentrations of $\mathrm{H}$-acid, at $400 \mathrm{ppm}(1.2 \mathrm{mM}) 87 \%$, at $450 \mathrm{ppm}(1.35 \mathrm{mM}) 80 \%$ and a lowest of $57 \%$ at $500 \mathrm{ppm}(1.5 \mathrm{mM})$ in $24 \mathrm{~h}$. Efficiency of degradation of $\mathrm{H}$-acid by A. latus immobilized in Ca-alginate continuously decreased above $200 \mathrm{ppm}(0.6 \mathrm{mM})$ to record lowest of $33 \%$ degradation at $500 \mathrm{ppm}(1.5 \mathrm{mM})$ in $48 \mathrm{~h}$. However, at $350 \mathrm{ppm}(1.05 \mathrm{mM})$ concentration of $\mathrm{H}$-acid, degradation in free cells was only $23 \%$ compared to $60 \%$ by cells immobilized in Ca-alginate and $100 \%$ with cells immobilized in polyurethane foam.

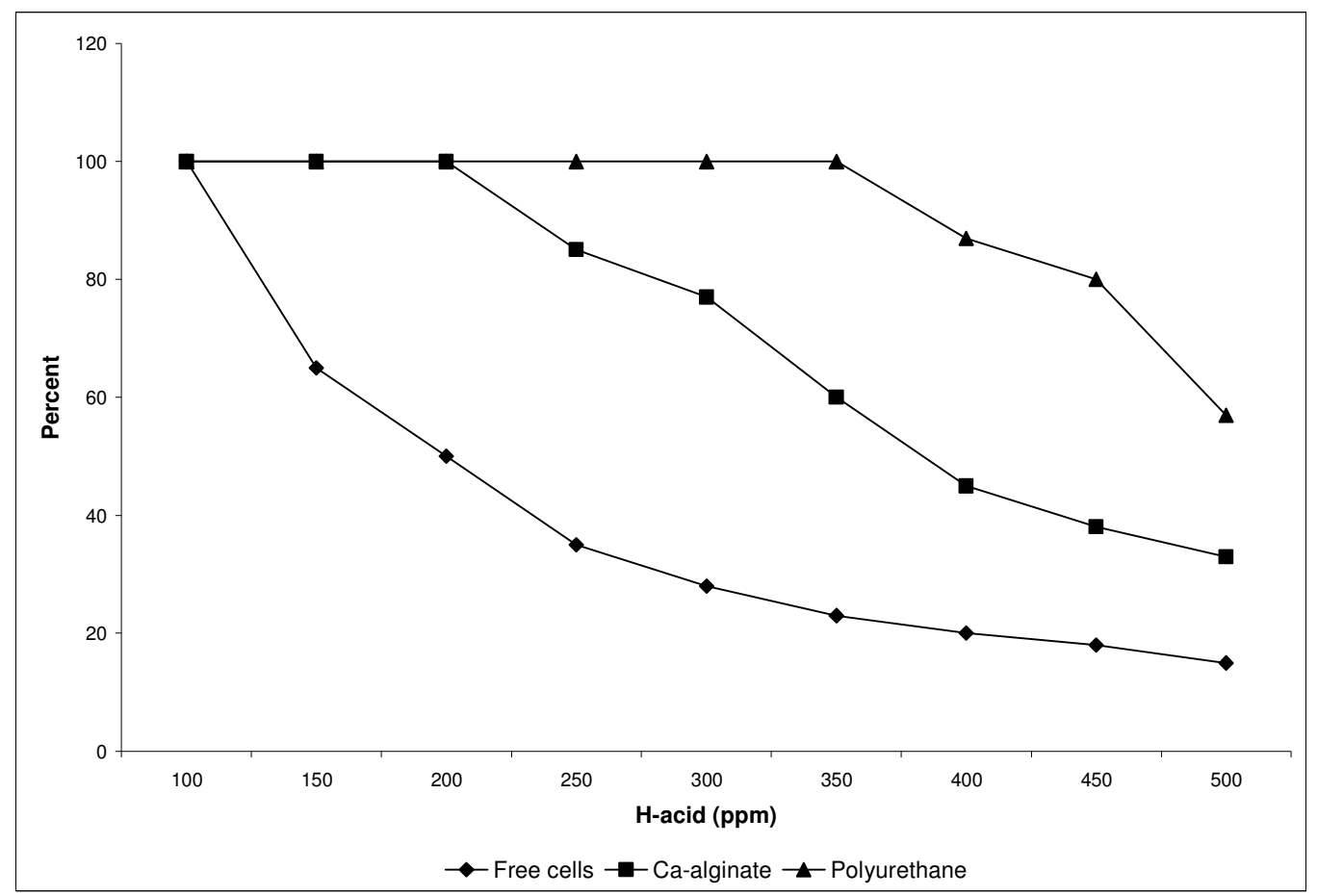

Figure 2. Batch degradation of $\mathrm{H}$-acid by free and immobilized cells of A. latus

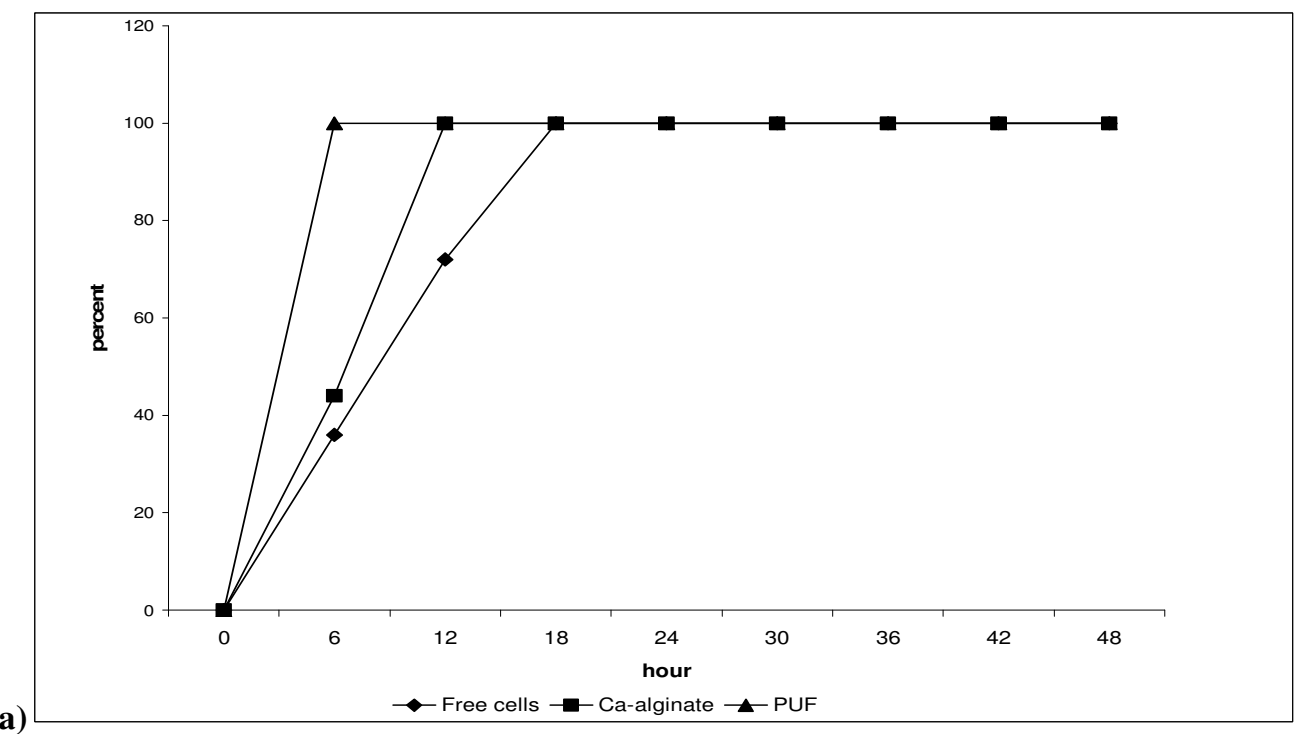



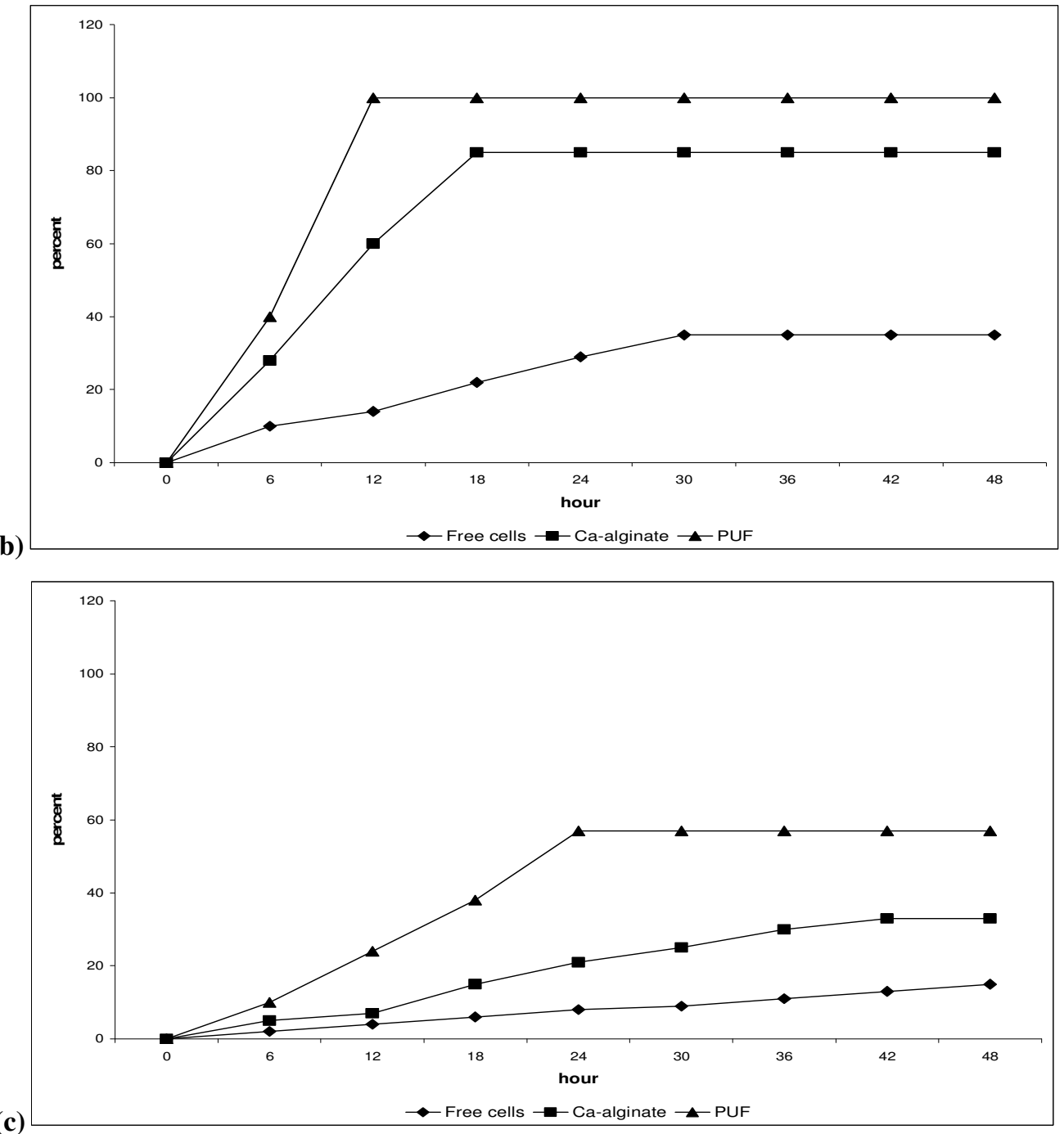

Figure 3. Time required for maximum degradation of $\mathrm{H}$-acid by free and immobilized cells at different concentration of $\mathrm{H}$-acid (a) $100 \mathrm{ppm}$ (b) $250 \mathrm{ppm}$ (c) $500 \mathrm{ppm}$

Free cells were able to show $100 \%$ degradation at 100 ppm $(0.3 \mathrm{mM})$ of $\mathrm{H}$-acid for which $18 \mathrm{~h}$ of incubation was required. Further increase in concentration resulted in decrease in per cent degradation and increase in incubation period. From $350 \mathrm{ppm}(1.05 \mathrm{mM})$ onwards the per cent degradation of $\mathrm{H}$ acid was reduced to less than $25 \%$ which required more than 30 $\mathrm{h}$ of incubation. With Ca-alginate immobilized cells upto 200 $\operatorname{ppm}(0.6 \mathrm{mM})$ of $\mathrm{H}$-acid $100 \%$ degradation was seen within 18 $\mathrm{h}$ of incubation after which the per cent degradation started reducing. At $500 \mathrm{ppm}(1.5 \mathrm{mM})$ of $\mathrm{H}$-acid only $33 \%$ degradation was recorded after $42 \mathrm{~h}$. However with polyurethane immobilized cells $100 \%$ degradation was recorded upto $350 \mathrm{ppm}(1.05 \mathrm{mM})$ concentration within $18 \mathrm{~h}$ and reduction of per cent degradation at further concentration was less. At $500 \mathrm{ppm}(1.5 \mathrm{mM}$ of $\mathrm{H}$-acid upto $57 \%$ degradation was recorded after $24 \mathrm{~h}$ of incubation.

The results of repeated batch $\mathrm{H}$-acid degradation are presented in Figure 4. From the figure it can be observed that Ca-alginate immobilized $A$. latus could be reused without changing its degradation efficiency upto 5 cycles and efficiency decreased to $88 \%$ upto 10 cycles, but with further increase in cycles resulted in decrease in degradation 
efficiency. However, even after 25 cycles $50 \%$ degradation efficiency was retained. PUF immobilized A. latus showed $100 \%$ degradation upto 7 cycles and decrease in the degradation capacity was observed after 7 cycles. And $87 \%$ degradation was recorded after 15 cycles and the efficiency remained $80 \%$ even after 25 cycles. From the observations it is clear that the PUF immobilized system was more efficient in biodegradation of $\mathrm{H}$-acid for an extended length of time when compared to cells embedded in $\mathrm{Ca}$-alginate.

During the recycling of immobilized microbial systems there was a leakage of cells from the matrix on repeated washings with minimal mineral salts medium in case of caalginate immobilized cells and mineral salts medium in case of PUF immobilized cells. It was observed that the cell leakage was very higher $\left(1 \times 10^{3} \mathrm{CFU} / \mathrm{ml}\right)$ in Ca-alginate matrix than in PUF $\left(2 \times 10^{1} \mathrm{CFU} / \mathrm{ml}\right)$ after 19 cycles and 25 cycles respectively.

The results of percent degradation of $\mathrm{H}$-acid by continuous system of Ca-alginate immobilized A. latus cells are shown in Figure 5. This figure shows the effect of different concentrations of $\mathrm{H}$-acid on percent degradation of $\mathrm{H}$-acid by
A. latus at a constant flow rate of $20 \mathrm{ml} / \mathrm{h}$. Complete degradation of $\mathrm{H}$-acid was recorded at flow rates of 20 (dt 180 $\mathrm{min})$ to $40 \mathrm{ml} / \mathrm{h}(\mathrm{dt} 90 \mathrm{~min})$ with $200 \mathrm{ppm}(0.6 \mathrm{mM})$ of H-acid and up to $20 \mathrm{ml} / \mathrm{hr}$ at $400 \mathrm{ppm}(1.2 \mathrm{mM})$ of $\mathrm{H}$-acid. On increasing the flow rate gradually from 40 to $100 \mathrm{ml} / \mathrm{h}$ (dt 36 min) the percent degradation also decreased, and even at 100 $\mathrm{ml} / \mathrm{h}$ flow rate percent degradation was $50 \%$ and $46 \%$ with 200 $(0.6 \mathrm{mM})$ and $400 \mathrm{ppm}(1.2 \mathrm{mM})$ respectively. At $1000 \mathrm{ppm}(3$ $\mathrm{mM}$ ) it was observed to be $74 \%$ degradation at $20 \mathrm{ml} / \mathrm{h}$ (dt 180 $\mathrm{min}$ ) flow rate and decreased to $22 \%$ at $100 \mathrm{ml} / \mathrm{h}$ (dt $36 \mathrm{~min}$ ).

The efficiency of PUF immobilized A. latus under continuous degradation of $\mathrm{H}$-acid is shown in Figure 6. A $100 \%$ degradation was observed at flow rates of 20 (dt 240 $\mathrm{min}$ ), 40 (dt $120 \mathrm{~min}$ ) and $60 \mathrm{ml} / \mathrm{h}(\mathrm{dt} 79.8 \mathrm{~min})$ at $200 \mathrm{ppm}$ (0.6 mM) of H-acid. Complete degradation was observed at lower flow rates with higher $\mathrm{H}$-acid concentrations, i.e. up to $400 \mathrm{ppm}(1.2 \mathrm{mM})$ at $20,40 \mathrm{ml} / \mathrm{hr}$ flow rates and at $20 \mathrm{ml} / \mathrm{h}$ flow rate up to $600 \mathrm{ppm}(1.8 \mathrm{mM})$ of $\mathrm{H}$-acid. Even at highest concentration of $1000 \mathrm{ppm}$ ( $3 \mathrm{mM}$ ) of $\mathrm{H}$-acid, $88 \%$ degradation was achieved at $20 \mathrm{ml} / \mathrm{h}$ (dt $240 \mathrm{~min}$ ) flow rate but only $42 \%$ degradation was observed with $100 \mathrm{ml} / \mathrm{h}$ (dt $48 \mathrm{~min}$ ) flow rate.

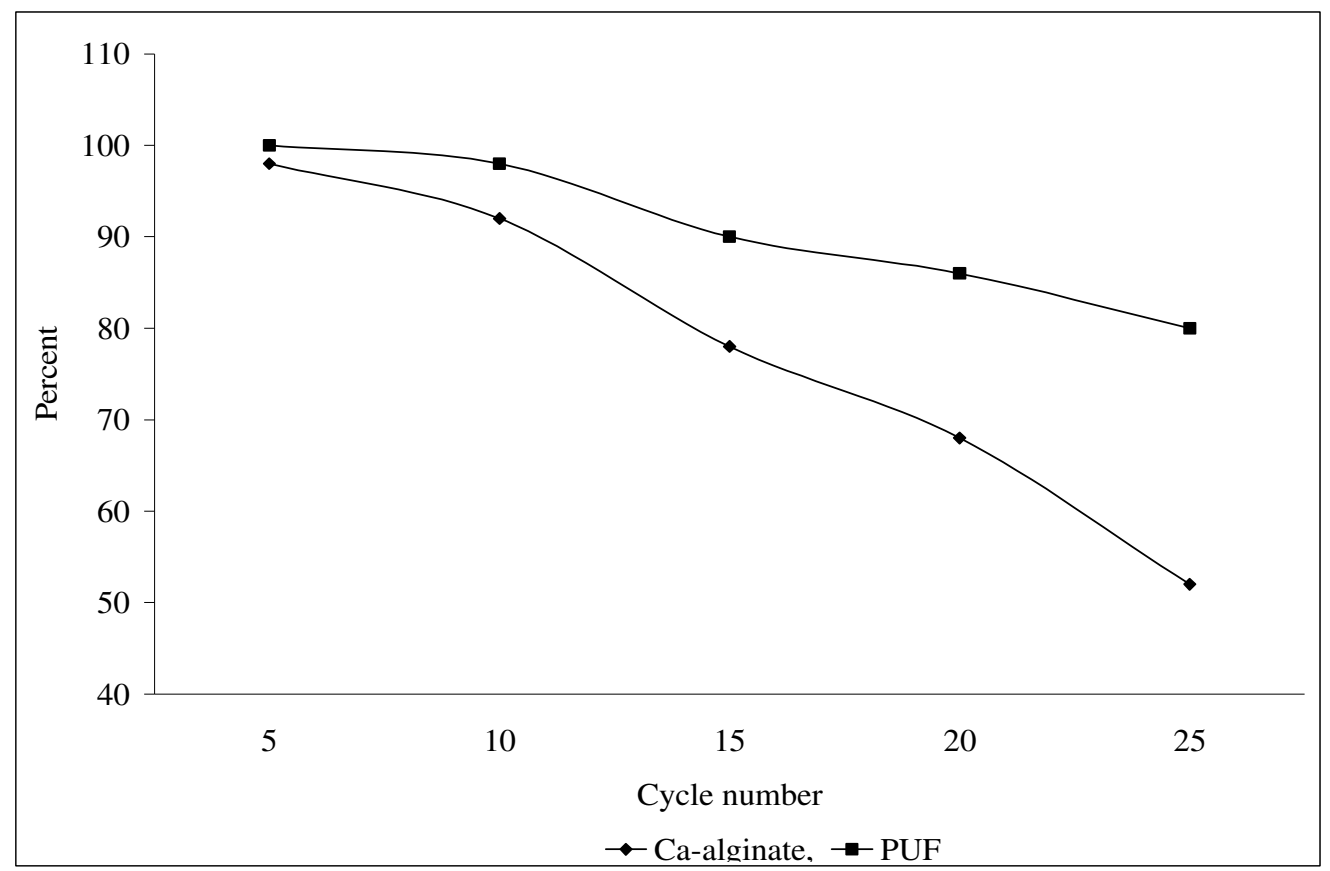

Figure 4. Repeated batch degradation of $\mathrm{H}$-acid at $200 \mathrm{ppm}$ concentration of $\mathrm{H}$-acid 


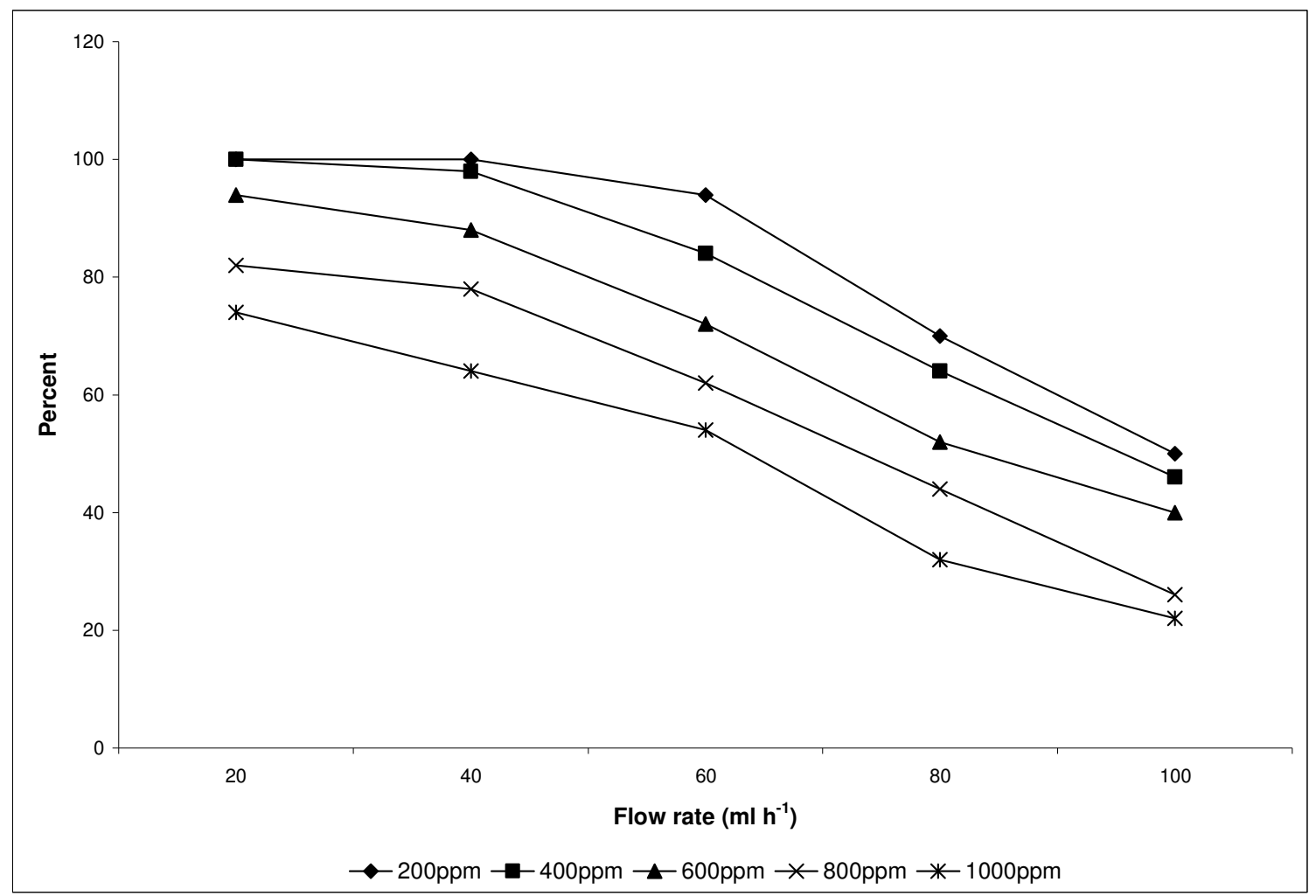

Figure 5. Continuous degradation of different concentrations of $\mathrm{H}$-acid by $\mathrm{Ca}$-alginate immobilized A. latus system

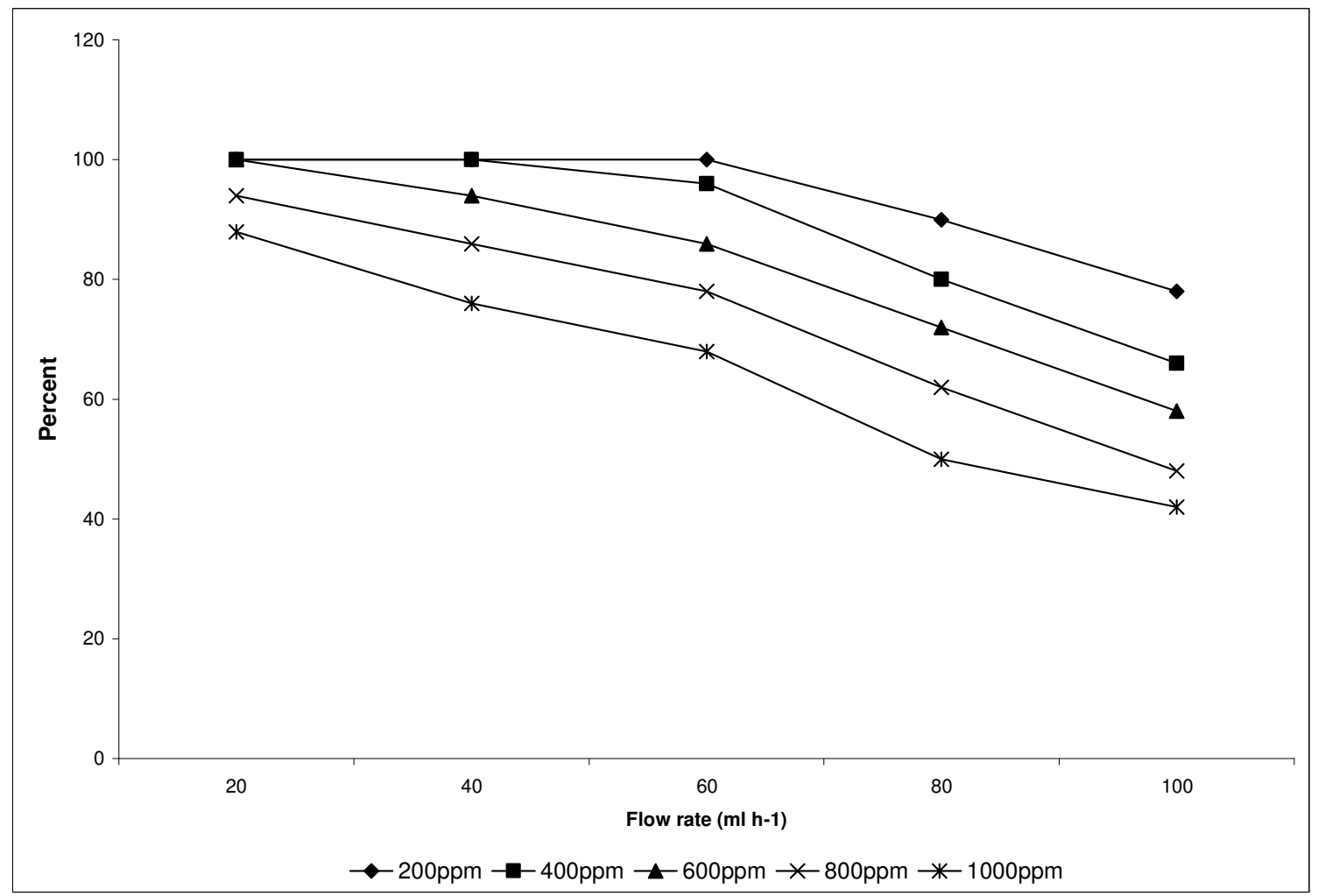

Figure 6. Continuous degradation of different concentrations of $\mathrm{H}$-acid by PUF immobilized A. latus system 
Cell viability was greater in PUF than Ca-alginate beads. After $2 \mathrm{~h}$ of immobilization cell viability was found to be $5 \times$ $10^{6} \mathrm{CFU} / \mathrm{ml}$ in PUF whereas it was $4 \times 10^{4} \mathrm{CFU} / \mathrm{ml}$ in $\mathrm{Ca}-$ alginate bead.

The products of $\mathrm{H}$-acid degradation by A. latus were separated and identified by TLC and spectral analyses.

The products of $\mathrm{H}$-acid degradation by $A$. latus were extracted with diethyl ether and subjected to TLC by various solvent systems. With Cyclohexane:Ethyl acetate:Acetone (4:1:1) and Chloroform:Acetone (80:20) as solvent system, a single broad band with tailing was observed not corresponding to the $\mathrm{H}$-acid band. $\mathrm{R}_{\mathrm{f}}$ values of $\mathrm{H}$-acid in two different solvent systems were found to be 0.23 and 0.19 and those of the product were found to be 0.33 and 0.28 . TLC bands were scraped out, extracted with diethyl ether and subjected to spectral analysis.

The H-acid, before subjecting to degradation, exhibited the IR and ${ }^{1} \mathrm{H}$ NMR spectra in concurrence with its structure. The IR showed a broad peak at $v 3499 \mathrm{~cm}^{-1}$ indicating merger of absorption peaks due to the vibrations of $\mathrm{vOH}$ and $\mathrm{vNH}_{2}$. The broad peak may be due to the hydrogen bonding between oxygen of $-\mathrm{OH}$ and hydrogen of $-\mathrm{NH}_{2}$. The next significant peak in the IR was at $v 1598 \mathrm{~cm}^{-1}$, indicating the absence of $\mathrm{C}=\mathrm{O}$ function in the molecule (Fig. 7).
The ${ }^{1} \mathrm{H}$ NMR of $\mathrm{H}$-acid exhibited distinguishable peaks from $6.6 \delta$ to $8.0 \delta$, which is the region for the absorption of aromatic protons, indicating the presence of aromatic character in the molecule. There is a distinguishable singlet seen at $3.3 \delta$, may be due to the resonance of $\mathrm{H}$ of phenolic $-\mathrm{OH}$. A sharp singlet is seen at $10.6 \delta$ accounting for two protons of primary aromatic amine $-\mathrm{NH}_{2}$. These spectral evidences support the structure assigned to $\mathrm{H}$-acid (Fig. 8).

The IR spectrum obtained for the degradation product showed a very weak peak at $v 3309 \mathrm{~cm}^{-1}$ indicating that percentage presence of molecule present in the mixture containing $-\mathrm{NH}_{2} /-\mathrm{OH}$ is very less. A very strong absorption peak was seen at $v 1731 \mathrm{~cm}^{-1}$ accounting for the presence of a molecule in the product containing $-\mathrm{C}=\mathrm{O}$ functionality (Fig. 9). These observations indicate that the $\mathrm{H}$-acid has undergone oxidative degradation to produce various non-aromatic molecules.

The above observation is further supported by the ${ }^{1} \mathrm{H}$ NMR spectrum of the product taken in DMSO- $\mathrm{d}_{6}$. None of the protons of the product resonated in the aromatic region of the spectra supporting the idea of disintegration of the molecule to produce number of aliphatic species (Fig. 10). This is further supported by the evidences that a good number of peaks due to the methyl proton are seen in the spectrum.

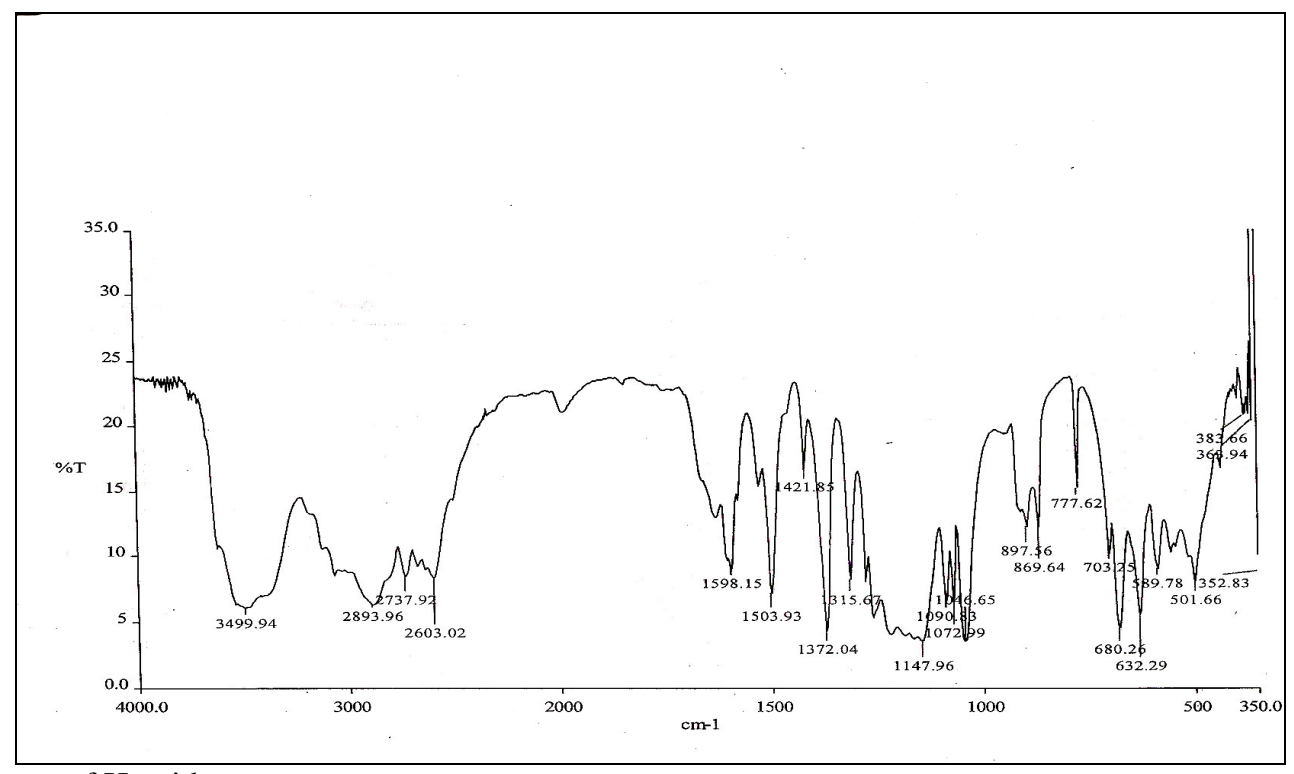

Figure 7. IR Spectrum of H-acid 


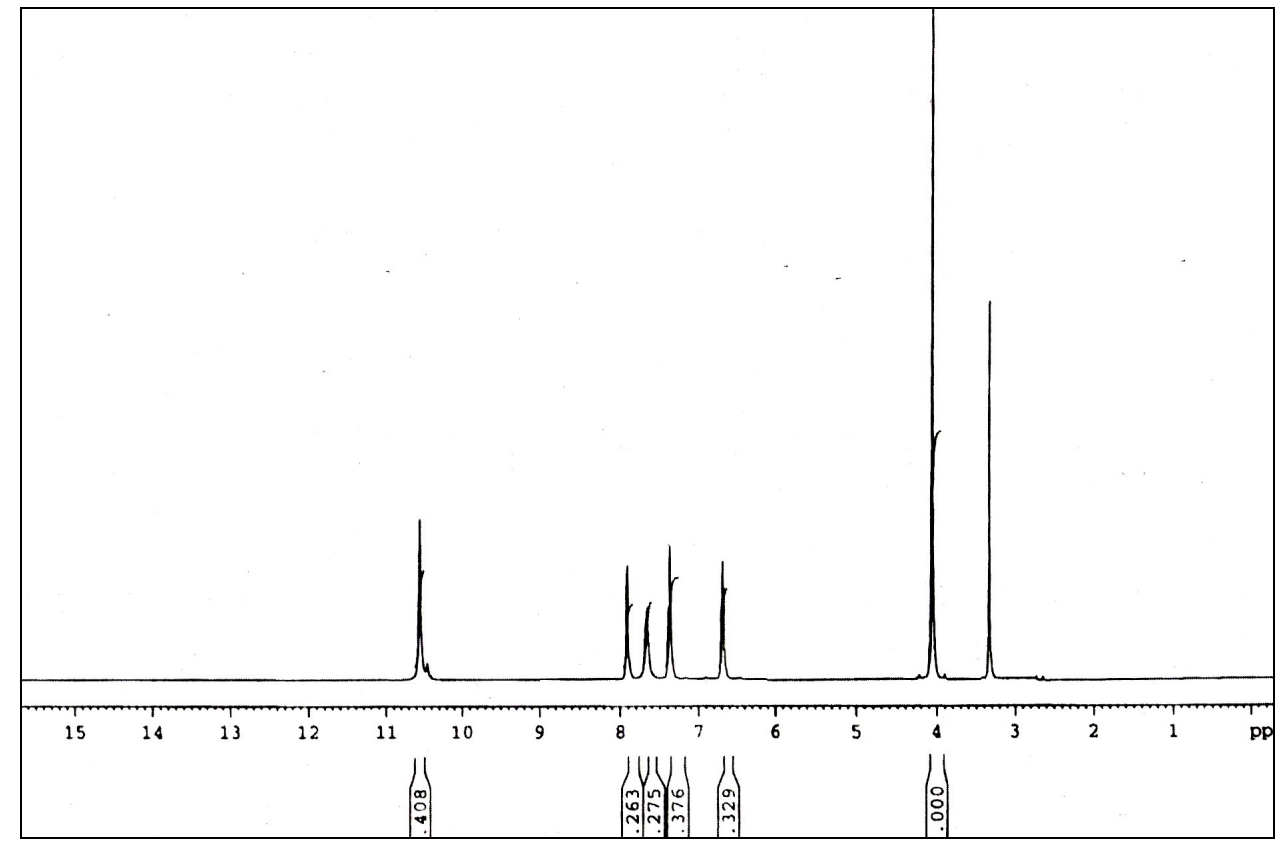

Figure 8. ${ }^{1} \mathrm{H}$ NMR Spectrum of $\mathrm{H}$-acid

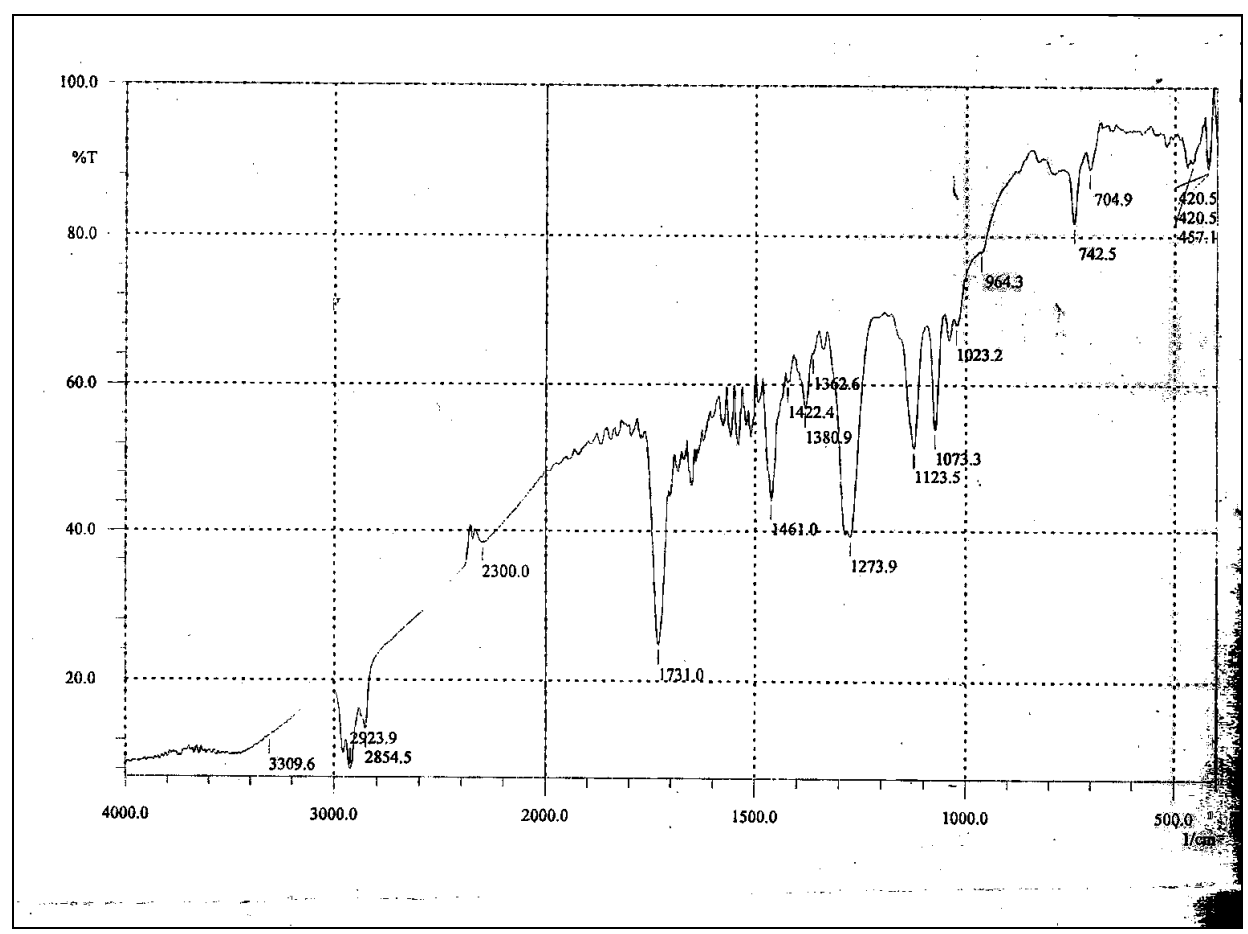

Figure 9. IR Spectrum of degradation product 


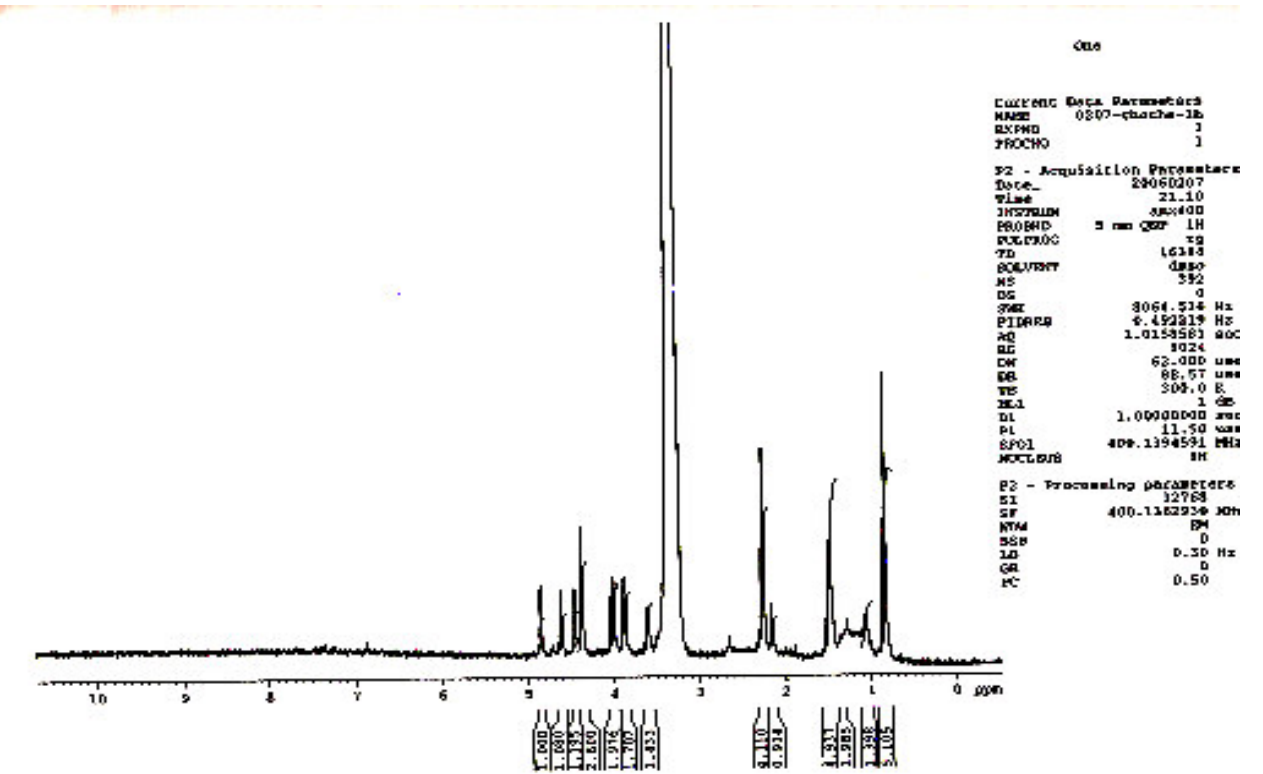

Figure 10. ${ }^{1} \mathrm{H}$ NMR Spectrum of degradation product

\section{DISCUSSION}

Results of batch degradation studies revealed that polyurethane foam immobilized cells were able to degrade $\mathrm{H}$ acid completely upto $350 \mathrm{ppm}(1.05 \mathrm{mM})$ compared to 200 ppm $(0.6 \mathrm{mM})$ with Ca-alginate immobilized cells and 100 ppm $(0.3 \mathrm{mM})$ with free cells in $48 \mathrm{~h}$. H-acid degradation efficiency of $A$. latus was observed to be reduced as the concentration of $\mathrm{H}$-acid increases.

The A. latus cells immobilized in the polyurethane foam showed higher degradation rate than the cells immobilized in Ca-alginate. This high rate of degradation may be attributed to the better availability of substrate (H-acid) to the cells as they are immobilized by adsorption process, whereas, with $\mathrm{Ca}$ alginate matrix the cells are embedded in the matrix, where the slow diffusion of substrate (H-acid) and air into the polymer beads may decrease the rate of degradation. Manohar and Karegoudar (30) and Sharanagouda and Karegouder (42) observed similar results with naphthalene degradation by immobilized Pseudomonas sp. It was also suggested that the storage stability and microbial activity of immobilized cells in polyurethane foam are known to be better than those cells immobilized in Ca-alginate $(4,9)$.
A. latus immobilized in $\mathrm{Ca}$-alginate and polyurethane foam showed complete degradation of $\mathrm{H}$-acid upto $400 \mathrm{ppm}$ and $600 \mathrm{ppm}$ respectively at a flow rate of $20 \mathrm{ml} / \mathrm{h}$. Increased degradation by immobilized cells was due to the accelerated reaction rates caused by the high local cell density in or on the immobilized matrix and also the immobilization of cells could improve the tolerance capacity against toxicity of high concentration of $\mathrm{H}$-acid. Immobilization also provides a kind of membrane stabilization, which was assumed to be responsible for the cell protection and better degradation rates in immobilized cells. Similar observations have been made by Hall and Rao (16) in the production of fuels and chemicals and Lee et al. (23) in the degradation of pyridine by immobilized Pimetobacter sp. It has been reported that immobilization of cells in a polymer matrix can confer protection from high levels of toxic compounds normally lethal to free cells. The protective effect may be due to adsorption of the toxic compound by the matrix, lowering the available concentration of the toxic compound in solution as observed with polyurethane foam (17), activated carbon (29) and beet chips (10). Alternatively it may be due to alteration in the membrane composition of cell in the matrix, rendering the membrane less permeable to toxic substances $(12,19)$. Immobilized viable 
cells have been shown to have altered metabolism, enhanced enzyme induction, altered macromolecules composition, and reduced specific cell growth and cell yield (14).

Repeated batch degradation studies were conducted to observe the effect of physicochemical factors on the degradation efficiency of A. latus immobilized in Ca-alginate and polyurethane foam. The results revealed that the polyurethane foam immobilized cells retained complete $\mathrm{H}$-acid degradation capacity for longer period (7 cycles) compared to cells immobilized in Ca-alginate ( 5 cycles). Cell leakage was almost three times more in $\mathrm{Ca}$-alginate compared to polyurethane foam immobilized cells after 25 cycles. Polyurethane foam showed higher mechanical stability, resistance to chemicals and biological degradation and lower cell leakage, that made it suitable for a long period reuse. Trevors et al. (46) observed mechanical instability and gradual cell leakage from Ca-alginate beads, decreasing the degradation rate. Enhancement in the activity of immobilized cells on reuse has been reported for the other systems $(18,39)$ and this may be due to post immobilization modifications/acclimatization. In contrast, our results on the reuse of immobilized beads/foam cubes did not show enhancement in the degradation of $\mathrm{H}$-acid but degradation rate decreased after several cycles of reuse. Similar observations were made by Sharanagouda and Karegoudar (42) in the degradation of 2-Methyl naphthalene using Pseudomonas sp.

The metabolic products produced from $\mathrm{H}$-acid degradation by $A$. latus were analyzed. Spectral scanning of the product showed a single peak at $260 \mathrm{~nm}$ and a single band on TLC which were not corresponding to $\mathrm{H}$-acid peak. Further analysis of TLC band by spectral analysis revealed the presence of a large number of small molecules suggesting the formation of aliphatic molecules during microbial utilization and aromatic byproducts were not observed. The IR spectrum of the products indicated the absence of sulphonic acid group suggesting that complete desulphonation occurs during the degradation of $\mathrm{H}$ acid. Similar reports have been given by Wittich et al. (48).

\section{ACKNOWLEDGEMENT}

I owe a deep sense of gratitude and appreciation to my Research Supervisor, Dr. C. T. Shivannavar, Reader, Department of Microbiology, Gulbarga University, Gulbarga for his valuable guidance. Thanks are due to SAIF, C.D.R.I., Lucknow and SAIF, I.I.Sc., Bangalore for providing NMR and IR and IMTECH, Chandigarh for identification of bacterium. Thanks are also due to Dr. Purohit, Retired professor, Department of Chemistry, Gulbarga University for interpreting spectral analysis data. I thank Gulbarga University, Gulbarga for providing Research Student Fellowship during my research work.

\section{REFERENCES}

1. Balfanz, J.; Rehm, H.J. (1991). Biodegradation of 4-chlorophenol by adsorptive immobilized Alcaligens sp. A 7-2 in soil. Appl. Microbiol. Biotechnol. 35, 662-668.

2. Bettman, H.; Rehm, H.J. (1984). Degradation of phenol by polymer entrapped microorganisms. Appl. Microbiol. Biotechnol. 20, 285-290.

3. Brilon, C.; Beckmann, W.; Hellwig, M.; Knackmuss, H.J. (1981). Enrichment and isolation of naphthalene sulphonic acid utilizing Pseudomonads. Appl. Environ. Microbiol. 42, 39.

4. Brouers, M.; Collard, F.; Jeanfils, J. et al. (1983). Soil Energy. Res. Dev. Eur. Community ser, D2, 171.

5. Cassidy, M.B.; Lee, H.; Trevors, J.T. (1996). Environmental applications of immobilized microbial cells: A review. J. Ind. Microbiol. 16, 79-101.

6. Cassidy, M.B.; Shaw, K.W.; Lee, H.; Trevors, J.T. (1997). Enhanced mineralization of pentachlorophenol by K-carrageenan - encapsulated Pseudomonas sp. UG30. Appl. Microbiol. Biotechnol. 47, 108-113.

7. Cheetham, P.S.J. (1980). Developments in immobilized cells and their applications. In: Wiseman A. (ed) Topics in enzyme and fermentation technology, Vol. 4, Ellis Harwood, Chichester, 189-238.

8. Chibata, I.; Tosa, T.; Sato, T. (1978). Preparation of immobilized enzymes and microbial cells. In: Chibata I(ed). Immobilized enzymes. Wiley, N.Y., 9-108.

9. Cocquempot, M.F.; Thomasset, B.; Barbotin, J.N. et al. (1981). Comparative stabilization of biological photosystems by several immobilization procedures. Eur. J. Appl. Microbiol. Biotechnol. 11, 193198.

10. Curtain, C.C. (1986). Understanding and avoiding ethanol inhibition. Trends Biotechnol. 4, 110. 
11. D'souza, S.F. (1989). Immobilized cells: Techniques and applications. Indian J. Microbiol. 29, 83-117.

12. Diefenbach, R.; Keweloh, H.; Rehm, H.J. (1992). Fatty acid impurities in alginate influence the phenol tolerance of immobilized Escherichia coli. Appl. Microbiol. Biotechnol. 36, 530-534.

13. Diekmann, R.; Hempel, D.C. (1989). Production rates of $\mathrm{CO}_{2}$ by suspended and immobilized bacteria degrading 6-amino 2-naphthalene sulfonic acid. Appl. Microbiol. Biotechnol. 32, 113-117.

14. Doran, P.M.; Bailey, J.E. (1986). Effects of immobilization on growth, fermentation properties, and macromolecular composition of Saccharomyces cerevisiae attached to gelatin. Biotechnol. Bioeng. 28, 73-87.

15. Feigel, B.J.; Knackmuss, H.J. (1993). Syntrophic interactions during degradation of 4-amino benzene sulphonic acid by a two species bacterial culture, Arch. Microbiol. 159, 124-130.

16. Hall, C.O.; Rao K.K. (1989). Immobilized photosynthetic membranes and cells for the production of fuels and chemicals. Chimicaoggi. 1, 4147.

17. Hu, Z.C.; Korus, R.A.; Levinson, W.E.; Crawford, R.L. (1994) Adsorption and biodegradation of pentachlorophenol by polyurethaneimmobilized Flavobacterium. Environ. Sci. Technol. 28, 491-496.

18. Joshi, N.T.; D'Souza, S.F. (1999). Immobilization of activated sludge for the degradation of phenol. J. Environ. Sci. Health-A. 34, 1689-1700.

19. Keweloh, H.; Heipieper, H.J.; Rehm, H.J. (1989). Protection of bacteria against toxicity of phenol by immobilization in calcium alginate. Appl. Microbiol. Biotechnol. 31, 383-389.

20. Klein, J.; Hackel, U.; Wagner, F. (1979). Phenol degradation by Candida tropicalis whole cells entrapped in polymeric ionic networks, p. 101-118. In. K. Venkatasubramanian (ed.). Immobilized microbial cells. ACS Symposium Series no.106. American Chemical society, Washington D. C.

21. Kneifel, H.; Elmendorff, K.; Hegewald, E.; Soeder, C.J. (1997). Biotransformation of 1-Naphthalene sulphonic acid by the green algae Scenedesmus obliquus. Arch. Microbiol. 167, 32-37.

22. Kulkarni, S.V.; Blackwell, C.D.; Blackard, A.L.; Stackocese, C.W.; Alexander, M.W. (1985). Textile dyes and dying equipment, classification, properties and environmental aspects, U.S. Environmental Protection Agency, EPA - 600/2 - 85/010. Research Trainage Par, NC.

23. Lee, S.T.; Rhee, S.K.; Lee, G.M. (1994). Biodegradation of pyridine by freely suspended and immobilized Pimelobacter sp. Appl. Microbiol. Biotechnol. 41, 652-657.

24. Manohar, S. (1999). Microbial degradation of aromatic hydrocarbons. Ph. D. Thesis, Gulbarga University, Gulbarga.

25. Manohar, S.; Kim, C.K.; Karegoudar, T.B. (2001). Enhanced degradation of naphthalene by immobilization of Pseudomonas sp. strain NGK1 in polyurethane foam. Appl. Microbiol. Biotechnol. 55, 311-316.

26. Mattiasson, B. (1983). Immobilization methods. P. 3-26. In. B. Mattiasson (ed.), Immobilized cells and organelles, Vol. I. CRC press,
Inc., Boca Raton, Fla.

27. Mohanty, S.; Rao, N.N.; Khare, P.; Kaul, S.N. (2005). A coupled photocatalytic-biological process for degradation of 1-amino-8-naphthol3, 6-disulfonic acid (H-acid). Wat. Res. 39, 5064-5070

28. Mordocco, A.; Kuek, C.; Jenkins, R. (1999). Continuous degradation of phenol at low concentration using immobilized Pseudomonas putida. Enzyme Microb. Technol. 25, 530-536.

29. Morsen, A.; Rehm, H.J. (1987). Degradation of phenol by a mixed culture of Pseudomonas putida and Cryptococcus elinovii adsorbed on activated carbon. Appl. Microbiol. Biotechnol. 26, 283-288.

30. Noorjahan, M.; Reddy, P.M.; Kumari, D.V. et al., (2003). Photocatalytic degradation of $\mathrm{H}$-acid over a novel $\mathrm{TiO}_{2}$ thin film fixed bed reactor and in aqueous suspensions. J. Photochem. Photobiol. A. 156, 179-187.

31. Nortemann, B.; Baumgarten, J.; Rast, H.G.; Knackmuss, H.J. (1986). Bacterial communities degrading Amino and Hydroxy Naphthalene 2sulfonates. Appl. Environ. Microbiol. 52, 1195-1202.

32. Nortemann, B.; Glasser, A.; Machinek, R.; Remberg, G.; Knackmuss, H.J. (1993). 5-Hydroxy quinoline 2-Carboxylic Acid, a dead end metabolite from the bacterial oxidation of 5-Aminonaphthalene 2sulfonic acid. Appl. Environ. Microbiol. 59, 1898-1903.

33. Nortemann, B.; Kuhm, A.E.; Knackmuss, H.J.; Stolz, A. (1994). Conversion of substituted Naphthalene sulfonates by Pseudomonas sp. BN6. Arch. Microbiol. 161, 320-327.

34. Nunez, M.J.; Lema, J.M. (1987). Cell immobilization: Application to alcohol production. Enzyme Microb. Technol. 9, 642-661.

35. O'Reilly, K.; Crawford, R.L. (1989). Degradation of pentachlorophenol by polyurethane-immobilized Flavobacterium cells. Appl. Microbiol. Biotechnol. 55, 2113-2118.

36. Perei, K.; Rakhely, G.; Kiss, I. et al. (2001). Biodegradation of sulfanilic acid by Pseudomonas paucimobilis. Appl. Microbiol. Biotechnol. 55, 101-107.

37. Pfennig, N.; Lippert, K.D. (1966). Uber das Vitamin B12-Bedurfnis phototropher Schwefelbakterien. Arch. Mikrobiol. 55, 245-256.

38. Rao, B.Y.K.; Godbole, S.S.; D’Souza, S.F. (1988). Preparation of lactose free milk by fermentation using immobilized Saccharomyces fragilis Biotechnol. Lett., 6, 427-430.

39. Rao, N.N.; Bose, G.; Khare, P. et al. (2006). Fenton and Electro-Fenton methods for oxidation of $\mathrm{H}$-acid and Reactive Black 5. J. Environ. Eng. $132,367-376$.

40. Rehorek, A.; Urbig, K.; Meurer, R.; Schäfer, C.; Plum, A.; Braun, G. (2002). Monitoring of azo dye degradation processes in a bioreactor by on-line high-performance liquid chromatography J Chromatogr A. 949, 263-8.

41. Reineke, W.; Knackmuss, H.J. (1978). Chemical structure and biodegradability of halogenated aromatic compounds: substituents effects on 1,2 dioxygenation of benzoic acid. Biochim. Biophys. Acta, 542, 412.

42. Sharanagouda, U.; Karegoudar, T.B. (2002). Degradation of 2methylnaphthalene by free and immobilized cells of Pseudomonas sp. 
strain NGK1. World J. Microbiol. Biotechnol. 18, 225-230.

43. Soeder, C.J.; Hegewald, E.; Kneifel, H. (1987). Green microalgae can use Naphthalene sulphonic acids as sources of sulfur. Arch. Microbiol. 148, 260-263.

44. Somerville, H.J.; Mason, J.R.; Ruffell, R.N. (1977). Benzene degradation by bacterial cells immobilized in polyacrylamide gel.Eur. J. Appl. Microbiol., 4, 75-85.

45. Swaminathan, K.; Sandhya, S.; Sophia, C.A. et al. (2003). Decolorization and degradation of $\mathrm{H}$-acid and other dyes using ferrous-hydrogen peroxide system. Chemosphere. 50, 619-625.

46. Trevors, J.T.; Elsas, V.J.D.; Lee, H. et al. (1992). Use of alginate and other carriers for encapsulation of microbial cells for use in soil
Microbiol. Rel. 1, 61-69.

47. Westmeier, F.; Rehm, H.J. (1987). Degradation of 4-chlorophenol in municipal wastewater by adsorptive immobilized Alcaligenes sp. A7-2. Appl. Microbiol. Biotechnol. 26, 78-83.

48. Wittich, R.M.; Rast, H.G.; Knackmuss, H.J. (1988). Degradation of Naphthalene 2, 6 and Naphthalene 1,6-disulfonic acid by a Moraxella sp. Appl. Environ. Microbiol. 54, 1842-1847.

49. Zollinger, H. (1987). Colour chemistry - synthesis, properties and application of organic dyes and pigments 92-102, VCH publishers, N.Y.

50. Zurrer, D.; Cook A.M.; Leisenger, T. (1987). Microbial desulfonation of substituted Naphthalene sulphonic acids and Benzene sulphonic acids. Appl. Environ. Microbiol. 53, 1459-1463. 